\title{
Assessing the Bi-Causal Relationship Between Private Investment and Public Investment in SSA: Evidence from Panel Vector Autoregression Approach
}

\author{
Samuel Kwaku Agyei \\ Department of Finance, School of Business, University of Cape Coast, Ghana
}

\begin{abstract}
Research on crowding-in crowding-out hypothesis have been many but show inconsistent results and neglect of the possibility of a bi-causal relationship between private and public investment. Using data from Sub-Saharan Africa (SSA) and based on a Panel Vector Autoregressive model (PVAR), the results show that public and private physical capitals are compliments and mutually dependent. Consequently, in SSA, public infrastructure attracts private investment much the same as private infrastructure but the response of private to public is faster. Thus, countries in SSA should undertake policies to bridge the public infrastructural gap as a means of attracting private investment for development. Also, private investors need to do more probably through lobbying or bargaining in order to attract public infrastructure early, when private investment lead public investment.
\end{abstract}

Keywords: Public investment, Private investment, crowding-in-out hypothesis, PVAR

DOI: $10.7176 / \mathrm{JESD} / 10-12-02$

Publication date:June $30^{\text {th }} 2019$

\subsection{Introduction}

Generally, empirical literature is divided on the directional effect of public investment on private investment (Aschauer, 1989a, 1990; Munnell, 1990; Deverajan, Easterly \& Pack, 1999; Asante, 2000; Erden \& Holcombe, 2005; Ghura \& Barry, 2010; Ajide \& Olukemi, 2012; Munthali, 2012). While some studies point to a crowdingin effects of public investment on private investment (Asante, 2000; Ghura \& Barry, 2010; Altin, Moisiu \& Agim, 2012) others claim public investment crowds-out private investment (Ajide \& Olukemi, 2012; Munthali, 2012; Tchouassi \& Ngangue, 2014). This dichotomy appears to be related to the stage of development of the economy of study (Belloc \& Vertola, 2004; Erden \& Holcombe, 2005; Munthali, 2008, 2012) and the type of government spending (Malizard, 2015). The search for a solution to whether public investment crowds in or crowds out private investment must also consider whether the benefits of a systemic approach could help resolve it. Unfortunately, however, this consideration is yet to receive the needed empirical attention in SSA, where governments are still considered as major economic players and even dictating the pace and direction of economic development.

This study used panel vector autoregressive approach (PVAR), which allows one to isolate the response of private investment (public investment) to changes in public investment (private investment), to fill the gap in existing literature. PVAR allows one to use the orthogonalized impulse-response functions to show how one variable of interest (private investment or public investment) responds to an orthogonal shock in another variable of interest (i.e. private investment or public investment). Thus, through orthogonalizing, we are able to achieve our interest of ascertaining the effect of one shock at a time while holding other shocks constant (Love \& Zicchino, 2006).

Section 2 discusses the application of PVAR to the estimation of the bi-causal relationship between private investment and public investment. Section 3 discusses the results and the conclusion is captured in section 4.

\subsection{Literature Review}

\subsection{Theoretical literature review}

The crowding-in crowding out hypothesis forms the theoretical framework for conducting this study. The theory explains that government activities in the general economy especially the financially the financial markets may improve or curtail private investment which is generally considered to be efficient in ensuring economic growth in both developed and developing economies. The hypothesis posit that when government compete with private enterprises for resources like finance, they muscle out private enterprises because the markets generally consider private enterprises to be relatively risky when compared with government entities (Tatom, 1991; Holtz-Eakin, 1994; Evans \& Karras, 1994; Deverajan et al, 1999). Reduction in economic growth as a result of inefficient allocation of scarce resources, stifling of private initiatives and sub-optimal productivity per worker are regarded as the almost natural consequences. On the other hand, supporters of the crowding in hypothesis argue that in situations where government activities facilitate or compliment private investment, government engagement in the financial markets would enhance private investment (Aschauer, 1989a, 1989b, 1990; Munnell, 1990).

The type of government investment as well as the developmental stage of the economy appears to explain which government spending crowds-in or crowds out private investment. Malizard (2015) concluded that even 
though military spending generally crowds out private investment, the type of military spending (non-equipment or equipment) explains whether public investment crowds out or crowds in private investment. He explained that while military equipment spending is related to the crowding out hypothesis, military non-equipment (consumption) spending is related to crowding in hypothesis. Similarly, Xiaoming and Yanyang (2014) postulated that, in China, government investment in public goods crowds in private investment while government investment in private goods, through state owned enterprises, crowds out private investment. However, Erden and Holcombe (2005) argued that it is rather the stage of development of an economy that explains whether public investment would crowd in or crowd out private investment. It is claimed that crowding out effect is associated with developed economies while crowding-in is related to developing economies (Belloc \& Vertola, 2004; Erden \& Holcombe, 2005; Munthali, 2008, 2012). Mahmoudzadeh, Sadeghi and Sadeghi (2017) supported a crowding effect for both developed and developing economies but argued that this effect is stronger in developing economies than developed economies

\subsection{Empirical literature review}

Empirical findings in SSA, have followed the global pattern. For instance, Asante (2000) and Altin et al., (2012) argue in favour of crowding-in effect but Deverajan et al., (1999), Ajide and Olekumi (2012) favour the crowdingout hypothesis. Oshikoya (1994) document that public investment crowds in private investment using data from 1970 to 1988 that covered seven African countries (Cameroon, Mauritius, Morocco, Tunisia, Kenya, Malawi and Tanzania). Similar results were found by Mlambo and Oshikoya (2001) after expanding the sample size to 18 countries and the time frame to 1996 and also factoring in some macroeconomic variables and political stability. At the country level, Asante (2000) provides support for crowding-in using data from Ghana (see similar results for Kenya (Maana, Owino, \& Mutai, 2008).

Evidence also exists in SSA in support of the crowding-out hypothesis. Ndikumana (2000) uses data from 31 Sub-Saharan African (SSA) countries between 1970 and 1995 to conclude that credit to government crowds out private investment. Similarly, Tchouassi and Ngangue (2014) recently corroborated the crowding out hypothesis, using 14 selected Africa countries (13 SSA countries and Tunisia). Based on data from Nigeria, Ajide and Olekumi (2012) offer support for the crowding out hypothesis, corroborating that of Bakare (2011). Similar results were recorded for Malawi (Assa \& Abdi, 2012); Argentina (Acosta \& Loza, 2005); and India (Pradhan, Ratha \& Sarma, 1990; Mitra, 2006). de Wit and Bekkers (2016) concluded that most studies (two-thirds of studies reviewed) concluded that public funding of non-profit making organisations displaces private donations rather than compliment it. Tan, Huan and Woo (2016) concluded that government support for insolvent firms (zombie firms) that stay in operation enhanced their performance but crowded out the growth of private firms.

There is also evidence in support of the fact that not all studies were able to conclude on whether public investment crowds in or crowds out private investment. Nyamongo and Misati (2011) controlled for economic growth, public investment, fiscal deficit, financial sector development, corruption and economic freedom but report that public investment has an insignificantly negative relationship with private investment. Meanwhile the relationship between fiscal deficit and private investment was significantly negative. Munthali (2012) factored in the accelerator effects, cost of capital, capital availability, risk and uncertainty, economic freedom and profitability in southern Africa but found that even though public investment exerts a positive relationship with private investment, this relationship is not significant.

Surprisingly, researchers' attention appears to be over-concentrated on the effect of public investment on private investment, ignoring the possibility of a reverse causality. In developed economies, it is not uncommon for public investments in roads, water, telecommunication and electricity to lead private commercial or household investment. But in developing economies like Africa, private investments may prompt public investment (Sturm, 2001). In other words, attention of governments in developing economies is sometimes drawn to the provision of basic infrastructure for certain areas of their economy because of private investment activities in such areas. Also, in some cases, government investment activities are undertaken in certain sectors of the economy, like provision of transport services, because private sector involvement brings hardship to its citizens. Furthermore, the way in which public investments are funded would also play a key role in helping to resolve the crowding-in and crowding-out debate. Where public investments are funded through internally generated funds of government and not on the meagre domestic credit, the crowding out effect of public investment on private is likely to be minimal. Thus, private investment activities may attract or reduce public investment.

Unfortunately, to the best of the researcher's knowledge, the abundant literature on the crowding-in-out debate seems to have ignored this important issue, especially in SSA. The closest studies are from Munthali (2012) and Agyei (2017). Munthali (2012) only acknowledged the worthiness of a study that assesses the possibility of bi-causal relationship, but failed to test for it while Agyei (2017) concentrated on whether private investment crowds out or crowds in public investment even in the presence of good governance structures. His study concluded that private investment crowds out public investment, even in the presence of country governance structures such as control of corruption, political stability, rule of law, governance effectiveness, voice and 
accountability and regulatory quality). Following the pattern of previous studies, Agyei (2017) never considered the relationship between private and public investment in a form of a system, which this study considers necessary in resolving the crowding-in-crowding-out hypothesis.

\subsection{Methodology}

\subsection{Panel Vector Autoregression Approach}

A panel-data vector autoregression (PVAR) approach introduced by Holtz-Eakin, Newey and Rosen (1988) has the ability to simultaneously estimate a system of equations like the one specified in equations 2,3 and 4 below. All variables in the specified system are assumed to be endogeneous and each variable is regressed on its lagged values and the lagged values of all other variables in the system, after controlling for the unobserved individual heterogeneity in that system of equations. Thus, the approach combines the advantages of normal vector autoregression approach and benefits from panel data analysis.

Following Love and Zicchino (2006), Ahlfeldt, Moeller and Wendland (2014), Abrigo and Love (2015), a $k$ variate PVAR model of order $p$ with country specific and time specific fixed effects can be specified generally as follows:

$$
\begin{aligned}
& Y_{i t}=A_{1} Y_{i t-1}+A_{2} Y_{i t-2}+\ldots+A_{p} Y_{i t-p}+u_{i}+v_{t}+e_{i t} \\
& \qquad \quad i \in\{1,2, \ldots . .48\}, t \in\{1,2, \ldots 20\} \\
& \qquad Y_{i t} \text { is a }(1 \mathrm{x} k) \text { vector of dependent variables (public investment, LNGPINV; private investment, }
\end{aligned}
$$
LNPRINV; and economic growth per capita, $\left.\operatorname{LNGDP}_{\mathrm{it}-1}\right) ;{ }^{u_{i}}, v_{t}$ and $e_{i t}$ is the $(1 \mathrm{x} k)$ vectors of dependent variable-specific country and time fixed-effects and idiosyncratic errors, respectively. The $(k x k)$ matrices $A_{1}, A_{2}$ ,... and $A_{p}$ are parameters to be estimated. The innovations are assumed to have the following characteristics: $E\left[e_{i t}\right]=0, E\left[e_{i t}^{\prime} e_{i t}\right]=\sum$ and $E\left[e_{i t}^{\prime} e_{i s}\right]=0$ for all $t>s$. The estimation of the above parameters, either jointly with the fixed-effects or separately (after some transformation) using equation-by-equation ordinary least squares would lead to biased results even with large $N$, because of the presence of lagged dependent variables in the independent variables of the system of equations (Nickell, 1981; Abrigo \& Love, 2015). This bias cannot be assumed to be getting to zero in this particular study, as is generally considered when $T$ becomes larger, because significant bias was found by Judson and Owen (1999) even when $T=30$. One way to eliminate this bias and offer consistent results, especially with small $T$ and large $N$, is to base the estimations on the General Methods of Moments (GMM) conditions. This method uses the lagged levels of endogenous regressors as instruments and transforms the data by first differencing it (Holtz-Eakin et al., 1988).

The inclusion of the time specific and country specific dummies in equation (1) makes the model for the system of equations close to reality, by showing that the underlying structure is not the same for each crosssectional unit. Meanwhile, these variables may be correlated with the other regressors because of the lagged dependent variables. The time-specific dummies are eliminated through the differencing approach. The country specific dummies are eliminated by applying the 'Helmert procedure' which uses the forward mean-differencing approach to remove only the forward mean, the mean of all future observations available for each country. The 'Helmert procedure' preserves the orthogonality between transformed variables and lagged regressors so that the lagged regressors can be used as instruments and the coefficient of the system of equations estimated by system of GMM (Arellano \& Bover, 1995; Love \& Zicchino, 2006). Meanwhile, the application of the 'Helmert procedure' requires that all variables are time demeaned, first.

Generally, PVAR estimation requires that the variables should be stationary. In view of this, all the variables included in the system estimation were subjected to stationarity test using the Fisher-type unit root test because of the nature (large $\mathrm{N}$ and small $\mathrm{T}$ ) of the panel data used.

After estimating the PVAR, we also presented the impulse response functions (IRF) as well as the variance decompositions. The IRFs were estimated in order to assess the responses of private and public investments to shocks to any of these variables (private and public investment) and how long the effect of these shocks persist in the short run. The variance decomposition depicts the total percentage change in one variable which is explained by a shock in another variable, over a specific period. These were done with the intention of knowing the specific effects of private investment on public investment and vice versa when other factors are held constant. Based on the general PVAR form, the following specific system of equations was estimated:

$$
\begin{aligned}
& \text { LNGPINV }_{i t}=\alpha_{1} \text { LNGPINV }_{i t-1}+\beta_{1} \text { LNPRINV }_{i t-1}+\delta_{1} \text { LNGDP }_{i t-2}+u_{1 i}+v_{1 t}+e_{1 i t} \\
& \text { LNPRINV }_{i t}=\alpha_{2} L N G P I N V_{i t-1}+\beta_{2} L N P R I N V_{i t-1}+\delta_{2} L N G D P_{i t-2}+u_{2 i}+v_{2 t}+e_{2 i t}
\end{aligned}
$$




$$
L N G D P_{i t-1}=\alpha_{3} L N G P I N V_{i t-1}+\beta_{3} L N P R I N V_{i t-1}+\delta_{3} L N G D P_{i t-2}+u_{3 i}+v_{3 t}+e_{3 i t}
$$

where $\alpha, \beta$ and $\delta$ are parameters to be estimated in the equations in the system. The lag of economic growth per capita is used in the system in order to cater for the possibility of simultaneity between economic

growth and the two investment variables. Thus, $L N G D P_{i t-2}$ is the lag of the lag of economic growth per capita. All other variables assume the meaning as indicated in equation (1). Equation (2) in the system shows that current levels of public investment are not influenced by contemporaneous factors of private investment and economic growth because of the time-to-build effect but on its own previous levels, previous levels of private investment and economic growth. This is because, it is argued that public investment may follow private investment either to provide infrastructure to compliment private investment efforts or offer competitive products/services in order to mitigate the hardship on its citizens. Meanwhile, public investment may follow economic growth because of the fact that resources may be available to fund them or in order to accelerate growth.

Equation (3) is premised on the assumption that private investment is influenced by its lag and the lags of public investment and economic growth. Public investment may precede private investment because the existence of good public infrastructure may serve as an attraction for private investment. Also, in some instances, private investors' means of entry into certain industries are based on acquisition of existing public investments. Private investors use economic growth to gauge the attractiveness of economies and either follow it or not. Equation (4) simply reiterate the widely held economic view that physical capital of an economy explains its growth and that because of the time-to-build effect such relationship is not expected to be contemporaneous. The study included data from all SSA countries except South Sudan. The exclusion of South Sudan was basically based on lack of data. In all, 48 countries were included in the study over a 20 year period, from 1990 to 2009.

\subsection{Discussion of Empirical Results}

\subsection{Unit Root Test Results}

The results from the unit root test, as shown in Table 1, suggest that the time-demeaned helmert transformed data used for the panel VAR estimations are stationary at their levels.

\section{Table 1: Panel Unit Root Test}

\begin{tabular}{llll} 
& LNGPINV & LNPRINV & LNGDP (-1) \\
\hline ADF-Fisher Chi-square & $181.828^{* * *}$ & $190.378^{* * *}$ & $127.850^{* * *}$ \\
ADF-Choi Z-stat & $-5.54731^{* * *}$ & $-6.12863^{* * *}$ & $-2.99246^{* * *}$ \\
No. of Obs. & 748 & 733 & 786 \\
\hline
\end{tabular}

$\frac{\text { No. of Obs. }}{{ }^{*} p<0.1,{ }^{* *} p<0.05,{ }^{* * *} p<0.01}$

\subsection{Presentation of PVAR Results}

The results of the estimated system of equations are presented in Table 2 below. The estimated coefficients are after the elimination of the country-specific and time-specific effects. The system of equations estimated has private, public investments and economic growth as the main variables of interest. Apparently the study offers support for the argument that past levels of both private and public acquisition of fixed assets help explain each other. In other words, the results suggests that previous levels of private investment in SSA serve as a source of attraction for government investment in the areas of infrastructure such as the provisions of electricity, roads, health and education. Thus, public investments follow private investment in SSA to provide basic public goods and other complimentary products. Similar results were recorded for economic growth. Previous levels of high economic growth are catalyst for subsequent additions to public investment either because of resource availability or positive signals picked by governments.

The results from the private investment model indicate that private and public investments are compliments even though, contrary to expectation, previous levels of economic growth appear to deter private investment. In other words, even though private investment may precede public investment in SSA, public investment in infrastructure also serves as an attraction for private investment. Unfortunately, however, private investors' confidence in the sustainability of previous economic growth levels seems to be minimal. In fact, in SSA, private investors appear to reduce their investment when preceding periods are characterised by high economic growth. Thus, private investors in SSA, expect a recession in periods following high economic growth, casting doubts on the sustainability of growth policies undertaken in the sub region.

The results support established growth theories that investment propels economic growth. Previous levels of both private and public investment have a positively significant relationship with current levels reiterating the fact that investment drives growth.

Consequently, both private and public investment in physical capital complement each other and eventually enhance economic growth but growth send different signals to both public and private investors in SSA. 
Table 2: Panel VAR Estimation Results

\begin{tabular}{|c|c|c|c|}
\hline & LNGPINV & LNPRINV & LNGDP2 \\
\hline \multirow[t]{2}{*}{ LNGPINV(-1) } & $0.637724 * * *$ & $0.094789 * * *$ & $-0.024046^{*}$ \\
\hline & $(0.03950)$ & $(0.03753)$ & $(0.01586)$ \\
\hline \multirow[t]{2}{*}{ LNGPINV(-2) } & 0.020806 & -0.027553 & $0.039051 * * *$ \\
\hline & $(0.03836)$ & $(0.03645)$ & $(0.01540)$ \\
\hline \multirow[t]{2}{*}{ LNPRINV(-1) } & $0.101372 * * *$ & $0.584907 * * *$ & $-0.035863 * * *$ \\
\hline & $(0.03942)$ & $(0.03746)$ & $(0.01583)$ \\
\hline \multirow[t]{2}{*}{ LNPRINV(-2) } & -0.049811 & $0.086620 * * *$ & $0.048113 * * *$ \\
\hline & $(0.03628)$ & $(0.03447)$ & $(0.01457)$ \\
\hline \multirow[t]{2}{*}{ LNGDP(-1) } & $0.348595 * * *$ & $-0.164049 * *$ & $0.887873 * * *$ \\
\hline & $(0.09719)$ & $(0.09234)$ & $(0.03902)$ \\
\hline \multirow[t]{3}{*}{ LNGDP(-2) } & $-0.2621 * * *$ & 0.042729 & $-0.056019^{*}$ \\
\hline & $(0.09465)$ & $(0.08993)$ & $(0.03800)$ \\
\hline & {$[-2.76918]$} & {$[0.47514]$} & {$[-1.47419]$} \\
\hline \multirow[t]{3}{*}{$\mathrm{C}$} & -0.003591 & -0.036829 & -0.041565 \\
\hline & $(0.01848)$ & $(0.01755)$ & $(0.00742)$ \\
\hline & {$[-0.19438]$} & {$[-2.09803]$} & {$[-5.60366]$} \\
\hline R-squared & 0.472566 & 0.532107 & 0.771557 \\
\hline Adj. R-squared & 0.467535 & 0.527644 & 0.769378 \\
\hline Sum sq. resids & 74.45456 & 67.21566 & 12.00123 \\
\hline S.E. equation & 0.344049 & 0.326896 & 0.138130 \\
\hline F-statistic & 93.92777 & 119.2207 & 354.0706 \\
\hline Log likelihood & -220.3319 & -187.806 & 360.0754 \\
\hline Akaike AIC & 0.714880 & 0.612597 & -1.1103 \\
\hline Schwarz SC & 0.763915 & 0.661633 & -1.061265 \\
\hline Mean dep. & -0.069438 & -0.065701 & -0.25458 \\
\hline S.D. dependent & 0.471493 & 0.475636 & 0.287632 \\
\hline No. of Obs. & 636 & 636 & 636 \\
\hline \multicolumn{2}{|c|}{ Determinant resid covariance (dof adj.) } & 0.000239 & \\
\hline \multicolumn{2}{|c|}{ Determinant resid covariance } & 0.000231 & \\
\hline \multicolumn{2}{|c|}{ Log likelihood } & -45.17886 & \\
\hline \multicolumn{2}{|c|}{ Akaike information criterion } & 0.208110 & \\
\hline \multicolumn{2}{|l|}{ Schwarz criterion } & 0.355215 & \\
\hline
\end{tabular}

$* * *=1 \%, * *=5 \%$ and $*=10 \%$

Where GPINV is public investment; PRINV is private investment; and GDP is gross domestic product.

\subsection{Impulse Response Functions (IRF)}

Based on the results of the reduced form equation estimated and shown in Table 2, the IRF graphs as (shown in Figure 1) and Appendix 3 have been derived. The IRF shows how much a variable in the system would change if there is a shock or an innovation to another variable and how long such a change would persist in the short run.

Generally, the results from the IRF support that of the PVAR results showing that public investment and private investment are positively mutually dependent. It is observed that a $1 \%$ shock to private investment, even though does not depict any change in period 1, shows a positive change in public investment by 0.031 (in logs) in the second period. This effect trickles down to the ten periods observed, albeit with reducing effect. The delay in the effect of a shock to private investment on public investment could be assigned to the time-to-build effects especially on the part of public investors. Similar results are observed for the lag of economic growth.

Furthermore, the results also show that a 1 percent shock to public investment exhibits a negative effect on private investment in the first period but positive effects in the subsequent periods (2 to 10). It is also observed that while periods 1 to 4 witnesses an increasing effect, periods 5 to 10 exhibits diminishing effects. The negative effect in the first period could be assigned to the fact that public investments, especially in the area of construction of roads and bridges sometimes lead to displacement of some private settlements and businesses. But when these investment projects are completed they tend to attract private investment. Meanwhile, the results depict that shocks to the lag of economic growth exhibit a negative effect on private investment, after the first period.

Thus, the effect of shocks to both private and public investments on each other is positive but with one period delayed effect which is not homogenous. 
Response of H_DMNLNGPIGDP to H_DMNLNGPIGDP

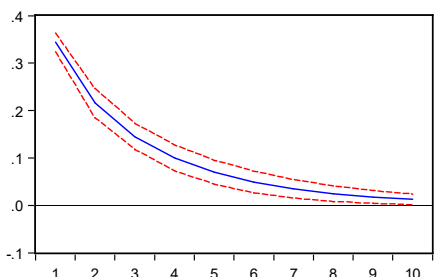

Response of H_DMNNLGFCFPS to H_DMNLNGPIGDP

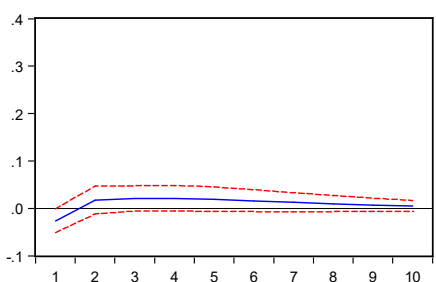

Response of $\mathrm{H} \_D M N N L G D P P C 2$ to H_DMNLNGPIGDP

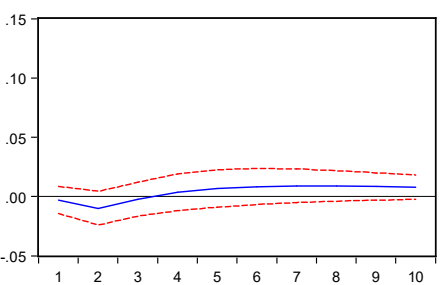

Response to Cholesky One S.D. Innovations \pm 2 S.E.

Response of H_DMNLNGPIGDP to H_DMNNLGFCFPS

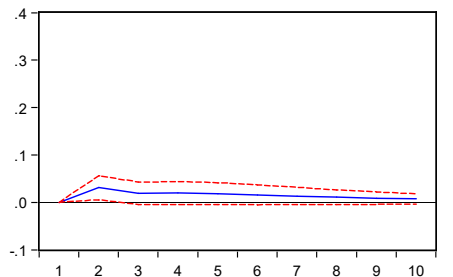

Response of H_DMNNLGFCFPS to H_DMNNLGFCFPS

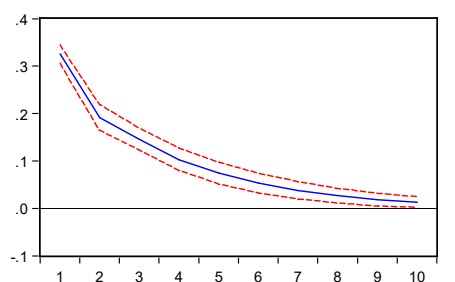

Response of H_DMNNLGDPPC2 to H_DMNNLGFCFPS

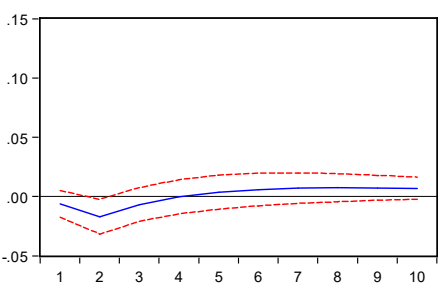

Response of H_DMNLNGPIGDP to H_DMNNLGDPPC2

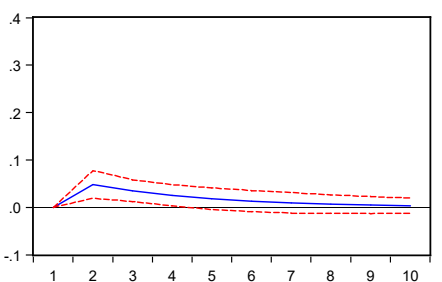

Response of H_DMNNLGFCFPS to H_DMNNLGDPPC2

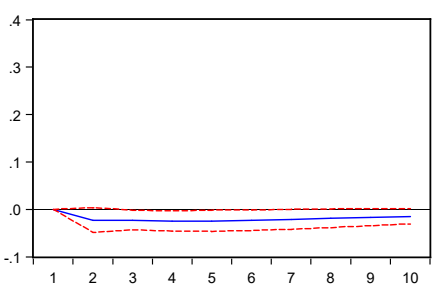

Response of H_DMNNLGDPPC2 to H_DMNNLGDPPC2

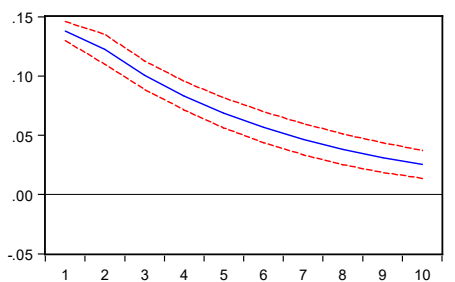

Figure 1: Impulse Response Graphs based on Authors' Estimated PVAR.

\subsection{Granger Causality}

The establishment of bi-causal relationships among the variables in the system of equations makes it imperative to estimate whether the variables granger cause each other and to what extent. The results of the granger causality, as depicted in Table 3 below, show that the null hypotheses that each of the variables in the system (public investment, private investment and economic growth) does not granger cause each other is rejected. Thus, it is observed that each of the variables in the system granger causes each other, confirming a bi-causal relationship between each pair and the suspicion of the existence of mutual dependency.

Table 3: Granger Causality Results of the Estimated System Variables.

\begin{tabular}{|c|c|c|c|}
\hline \multicolumn{4}{|c|}{ Dependent variable: LNGPINV } \\
\hline Excluded & Chi-sq & Df & Prob. \\
\hline LNPRINV & 7.055067 & 2 & 0.0294 \\
\hline $\operatorname{LNGDP}(-1)$ & 13.49447 & 2 & 0.0012 \\
\hline All & 19.56045 & 4 & 0.0006 \\
\hline \multicolumn{4}{|c|}{ Dependent variable: LNPRINV } \\
\hline Excluded & Chi-sq & Df & Prob. \\
\hline LNGPINV & 8.160320 & 2 & 0.0169 \\
\hline $\operatorname{LNGDP}(-1)$ & 8.284912 & 2 & 0.0159 \\
\hline All & 14.91521 & 4 & 0.0049 \\
\hline \multicolumn{4}{|c|}{ Dependent variable: LNGDP(-1) } \\
\hline Excluded & Chi-sq & Df & Prob. \\
\hline LNGPINV & 6.518796 & 2 & 0.0384 \\
\hline LNPRINV & 10.92833 & 2 & 0.0042 \\
\hline All & 15.90552 & 4 & 0.0031 \\
\hline
\end{tabular}

Where GPINV is public investment; PRINV is private investment; and GDP is gross domestic product.

\subsection{Variance Decomposition}

Finally, the variance decomposition results, as shown in Table 4 and Appendix 2, for period 1 shows that public investment explains about 0.657 of the change in private investment and 0.047 of the change in economic growth but private investment and the economic growth do not explain any portion of the change in public investment. 
This result suggest that it takes a relatively longer time for public investment to respond to private investment and economic growth due probably to cost of public investment and political will. The results may also imply that it is relatively easier for private investors to enter investment areas that are lead by public investors because of weak entry barriers unlike the strong entry barriers normally erected by private investors when they are the first to enter a particular market.

Table 4: Variance Decomposition Results

\begin{tabular}{llccc}
\hline Percentage of variation in & & LNGPINV & LNPRINV & LNGDP(-1) \\
\hline Explained by & LNGPINV & 100.0000 & 0.000000 & 0.000000 \\
& LNPRINV & 0.656587 & 99.34341 & 0.000000 \\
& LNGDP(-1) & 0.047825 & 0.199902 & 99.75227 \\
\hline
\end{tabular}

Where GPINV is public investment; PRINV is private investment; and GDP is gross domestic product.

\subsection{Conclusion}

This study reassessed the unsettled crowding-in-out hypothesis by examining the possibility of a bi-causal relationship between private and public investments in SSA, using a panel vector autoregressive approach. We conclude that private and public investments are mutually dependent and that public physical capital compliments private physical capital. In other words, private investment crowds in public investment much the same way as public investment does to private investment. Consequently, in SSA, public infrastructure attracts private investment much the same as private infrastructure but the response of private investment to public investment is faster. Thus, countries in SSA should work hard to bridge the infrastructural gap as a means of attracting more private investment to key sectors of the economy. Private investors on the other hand need to do more, in terms of lobbying and bargaining in order to attract infrastructure into areas that they take the lead.

\section{References}

Abrigo, M. R., \& Love, I.(2015). Estimation of Panel Vector Autoregression in Stata: a Package of Programs.

Acosta, P. \& Loza, A. (2005). Short and long run determinants of private Investment in Argentina Journal of Applied Economics. VIII (2), 389-406.

Ahfeldt, G. M., Moeller, K. \& Wendland, N. (2014). Chicken or Egg? The PVAR Econometrics of Transportation. Spatial Economics Research Centre, SERC Discussion Paper No. 158.

Agyei, S. K. (2017). Explaining public investment dynamics in SSA: The role of country governance structures. Cogent Economics \& Finance, 5(1) 1323987. https://doi.org/10.1080/23322039.2017.1323987

Ajide, K. B., \& Olukemi, L. (2012). Modelling the Long-run Determinants of Domestic Private Investment in Nigeria. Asian Social Science, 8(13), 139-152. doi:10.5539/ass.v8n13p139

Altin, G., Moisiu, D. \& Agim, A. (2012). Crowding-out Effects of Public Investment on Private Investment: an empirical investigation. Journal of Business \& Economics Research (JBER), 10(5), 269-276.

Arellano, M., \& Bover, O. (1995). Another look at the instrumental variable estimation of error-components models. Journal of econometrics, 68(1), 29-51.

Assa, M., \& Abdi, E. K. (2012). Selected Macroeconomic Variables Affecting Private Investment in Malawi (No. 40698). University Library of Munich, Germany.

Asante, Y. (2000). Determinants of Private Investment Behaviour (No. 100). AERC Research Paper, Nairobi: African Economic Research Consortium.

Aschauer, D.A. (1989a). Is public expenditure productive? Journal of Monetary Economics. 23, 177-200.

Aschauer, D.A.( 1989b). Does public capital crowds out private capital? Journal of Monetary Economics 24, 17188.

Aschauer, D. A. (1990). Why is infrastructure important? Is there a shortfall in publiccapital investment? Alicia Munnell. Boston: Conference Series of Federal ReserveBank of Boston.

Bakare, A. S. (2011). A theoretical analysis of capital formation and growth in Nigeria. Far East Journal of Psychology and Business, 3(2), 11-24.

Belloc, M., \& P. Vertova. (2004). How does public investment affect economic growth in HIPC? An empirical assessment. Department of Economics, University of Sienna.

Devarajan, S., Easterly, W., \& Pack, H. (1999). Is Investment in Africa Too High or Too Low? Macro and Micro 
Evidence. Journal of African Economies, 10 (2), 81-108.

de Wit and Bekkers (2016). Government support and charitable donations: A meta-analysis of the crowding-out hypothesis. Journal of Public Administration Research and Theory, 27(2), 301-319.

Erden, L., \& Holcombe, R. (2005). The effects of public investment in developing economies. Public Finance Review, 33(5), 575-602.

Evans, P., \& Karras, G. (1994). Are government activities productive? Evidence from a panel of U.S. states. Review of Economics and Statistics 76(1), 1-11.

Ghura, D. \& Barry, G. (2000). Determinants of Private Investment: A Cross-Regional Empirical Investigation. Applied Economics, 32, 1819-1829.

Holtz-Eakin, D., Newey, W., \& Rosen, H. S. (1988). Estimating vector autoregressions with panel data. Econometrica, 56, 1371 - 1395.

Holtz-Eakin, D.( 1994). Public-sector capital and productivity puzzle. Review of Economics and Statistics, 76 (1), 12-21.

Judson, R. A., \& Owen, A. L. (1999). Estimating dynamic panel data models: a guide for macroeconomists. Economics letters, 65(1), 9-15.

Love, I. \& Zicchino, L. (2006). Financial development and dynamic investment behaviour: Evidence from panel VAR. The Quarterly Review of Economics and Finance, 46, 190-210.

Maana, I., Owino, R. \& Mutai, N. (2008). Domestic Debt and its Impact on the Economy - The Case of Kenya. A Paper Presented During the $13^{\text {th }}$ Annual African Econometric Society Conference in Pretoria, South Africa from $9^{\text {th }}$ to $11^{\text {th }}$ July 2008 pp. 1-27.

Mahmoudzadeh, M., Sadeghi, S., \& Sadeghi, S. (2017). Fiscal spending and crowding out effect: a comparison between developed and developing countries. Institutions and Economies, 5(1) 31 - 40.

Malizard, J. (2015). Does military expenditure crowd out private investment? A disaggregated perspective for the case of France. Economic Modelling, 46, 44-52.

Misati, R. N. \& Nyamongo, M. E. (2011). Financial development and private investment in Sub Saharan Africa. Journal of Economics and Business, 63, 139-151.

Mitra, P. (2006). Has Government Investment Crowded out Private Investment in India? The American Economic Review, 96(2), 337-341.

Mlambo, K., \& Oshikoya, T. W. (2001). Macroeconomic factors and investment in Africa. Journal of African Economies, $10($ suppl 2), 12-47.

Munthali, T. C. (2012) Interaction of public and private investment in Southern Africa: a dynamic panel analysis. International Review of Applied Economics, 26(5), 597-622. doi:10.1080/02692171.2011.624500.

Munnell, A. H. (1990). Why has productivity growth declined? Productivity and public investment. New England Economic Review, January/February, 3-22.

Munthali, T.C. (2008). Investment in Southern Africa: Interaction of the public and private sectors. PhD thesis, April 2008, University of Leeds, UK.

Ndikumana, L. (2000). Financial Determinants of Domestic Investment in Sub-Saharan Africa: Evidence from Panel Data. World Development, 28(2), 381-400.

Nickell, S. (1981). Biases in dynamic models with fixed effects. Econometrica: Journal of the Econometric Society, 1417-1426.

Oshikoya, T. W. (1994). Macroeconomic determinants of domestic private investment in Africa: an empirical analysis. Economic Development and Cultural Change, 42(3), 573-596.

Pradhan, B. K., Ratha, D. K. \& Sarma, A.(1990). Complementarity between public and private investment in India. Journal of Development Economics, 33, 101-116.

Sturm, J. E. (2001). Determinants of public capital spending in less-developed countries. University of Groningen.

Tan, Y., Huan, Y., \& Woo, W. T. (2016). Zombie firms and the crowding-out of private investment in China. Asian Economic Paper, 15(3), 32 - 55.

Tatom, J. A. (1991). Public Capital and Private Sector Performance. Fed. Res. Bank of St. Louis Rev., 73(3), 3-15.

Tchouassi \& Ngangue (2014). Private Investment and Public Investment in Africa: A time-series cross-country analysis. International Journal of Economics and Finance, 6(5), $264-273$.

Xiaoming X., \& Yanyang, Y. (2014). Does government investment crowd out private investment in China?, 
Journal of Economic Policy Reform, 17(1), 1-12. DOI:10.1080/17487870.2013.866897 
Appendix 1: Impulse Response Tables for the Estimated PVAR

Response of LNGPINV

\begin{tabular}{|c|c|c|c|}
\hline Period & LNGPINV & LNPRINV & LNGDP(-1) \\
\hline \multirow[t]{2}{*}{1} & 0.344049 & 0.000000 & 0.000000 \\
\hline & $(0.00936)$ & $(0.00000)$ & $(0.00000)$ \\
\hline \multirow[t]{2}{*}{2} & 0.215670 & 0.030876 & 0.048092 \\
\hline & $(0.01465)$ & $(0.01312)$ & $(0.01421)$ \\
\hline \multirow[t]{2}{*}{3} & 0.145106 & 0.018517 & 0.034915 \\
\hline & $(0.01355)$ & $(0.01125)$ & $(0.01163)$ \\
\hline \multirow[t]{2}{*}{4} & 0.100020 & 0.019801 & 0.025068 \\
\hline & $(0.01380)$ & $(0.01157)$ & $(0.01117)$ \\
\hline \multirow[t]{2}{*}{5} & 0.069783 & 0.017876 & 0.018004 \\
\hline & $(0.01290)$ & $(0.01122)$ & $(0.01117)$ \\
\hline \multirow[t]{2}{*}{6} & 0.048879 & 0.015543 & 0.012935 \\
\hline & $(0.01134)$ & $(0.01020)$ & $(0.01084)$ \\
\hline \multirow[t]{2}{*}{7} & 0.034431 & 0.013049 & 0.009215 \\
\hline & $(0.00962)$ & $(0.00892)$ & $(0.01019)$ \\
\hline \multirow[t]{2}{*}{8} & 0.024383 & 0.010717 & 0.006503 \\
\hline & (0.00799) & $(0.00759)$ & $(0.00933)$ \\
\hline \multirow[t]{2}{*}{9} & 0.017353 & 0.008653 & 0.004535 \\
\hline & $(0.00656)$ & $(0.00635)$ & $(0.00838)$ \\
\hline \multirow[t]{2}{*}{10} & 0.012405 & 0.006894 & 0.003114 \\
\hline & $(0.00535)$ & $(0.00525)$ & $(0.00741)$ \\
\hline \multicolumn{4}{|c|}{ Response of LNPRINV : } \\
\hline Period & LNGPINV & LNPRINV & LNGDP(-1) \\
\hline \multirow[t]{2}{*}{1} & -0.026488 & 0.325821 & 0.000000 \\
\hline & $(0.01331)$ & $(0.00900)$ & $(0.00000)$ \\
\hline \multirow[t]{2}{*}{2} & 0.017614 & 0.191588 & -0.022632 \\
\hline & $(0.01517)$ & $(0.01456)$ & $(0.01183)$ \\
\hline \multirow[t]{2}{*}{3} & 0.020484 & 0.145763 & -0.022878 \\
\hline & $(0.01364)$ & $(0.01185)$ & $(0.00906)$ \\
\hline \multirow[t]{2}{*}{4} & 0.021281 & 0.103145 & -0.024641 \\
\hline & $(0.01379)$ & $(0.01177)$ & $(0.00947)$ \\
\hline \multirow[t]{2}{*}{5} & 0.019028 & 0.074090 & -0.024343 \\
\hline & $(0.01308)$ & $(0.01121)$ & $(0.01001)$ \\
\hline \multirow[t]{2}{*}{6} & 0.015878 & 0.052809 & -0.023095 \\
\hline & $(0.01169)$ & $(0.01022)$ & $(0.01005)$ \\
\hline \multirow[t]{2}{*}{7} & 0.012564 & 0.037475 & -0.021248 \\
\hline & $(0.01008)$ & $(0.00906)$ & $(0.00969)$ \\
\hline \multirow[t]{2}{*}{8} & 0.009533 & 0.026402 & -0.019123 \\
\hline & $(0.00849)$ & $(0.00787)$ & $(0.00905)$ \\
\hline \multirow[t]{2}{*}{9} & 0.006956 & 0.018432 & -0.016922 \\
\hline & $(0.00704)$ & $(0.00674)$ & $(0.00827)$ \\
\hline \multirow{2}{*}{10} & 0.004871 & 0.012715 & -0.014774 \\
\hline & $(0.00579)$ & $(0.00572)$ & $(0.00743)$ \\
\hline
\end{tabular}




\begin{tabular}{|c|c|c|c|}
\hline Period & LNGPINV & LNPRINV & LNGDP(-1) \\
\hline \multirow[t]{2}{*}{1} & -0.003021 & -0.006176 & 0.137959 \\
\hline & $(0.00548)$ & $(0.00576)$ & $(0.00380)$ \\
\hline \multirow[t]{2}{*}{2} & -0.010005 & -0.017168 & 0.122490 \\
\hline & $(0.00710)$ & $(0.00722)$ & $(0.00648)$ \\
\hline \multirow[t]{2}{*}{3} & -0.002371 & -0.006835 & 0.100682 \\
\hline & $(0.00744)$ & $(0.00685)$ & $(0.00636)$ \\
\hline \multirow[t]{2}{*}{4} & 0.003502 & -0.000356 & 0.083301 \\
\hline & $(0.00800)$ & $(0.00725)$ & $(0.00633)$ \\
\hline \multirow[t]{2}{*}{5} & 0.006726 & 0.003628 & 0.068865 \\
\hline & $(0.00812)$ & $(0.00741)$ & $(0.00657)$ \\
\hline \multirow[t]{2}{*}{6} & 0.008345 & 0.005890 & 0.056710 \\
\hline & $(0.00783)$ & $(0.00725)$ & $(0.00672)$ \\
\hline \multirow[t]{2}{*}{7} & 0.008928 & 0.007021 & 0.046543 \\
\hline & $(0.00729)$ & $(0.00686)$ & $(0.00672)$ \\
\hline \multirow[t]{2}{*}{8} & 0.008854 & 0.007394 & 0.038081 \\
\hline & $(0.00664)$ & $(0.00633)$ & $(0.00656)$ \\
\hline \multirow[t]{2}{*}{9} & 0.008382 & 0.007280 & 0.031071 \\
\hline & $(0.00594)$ & $(0.00573)$ & $(0.00628)$ \\
\hline \multirow[t]{2}{*}{10} & 0.007690 & 0.006869 & 0.025286 \\
\hline & $(0.00526)$ & $(0.00511)$ & $(0.00592)$ \\
\hline
\end{tabular}

Source: Authors' computation from data taken from World Development Indicators (2012)

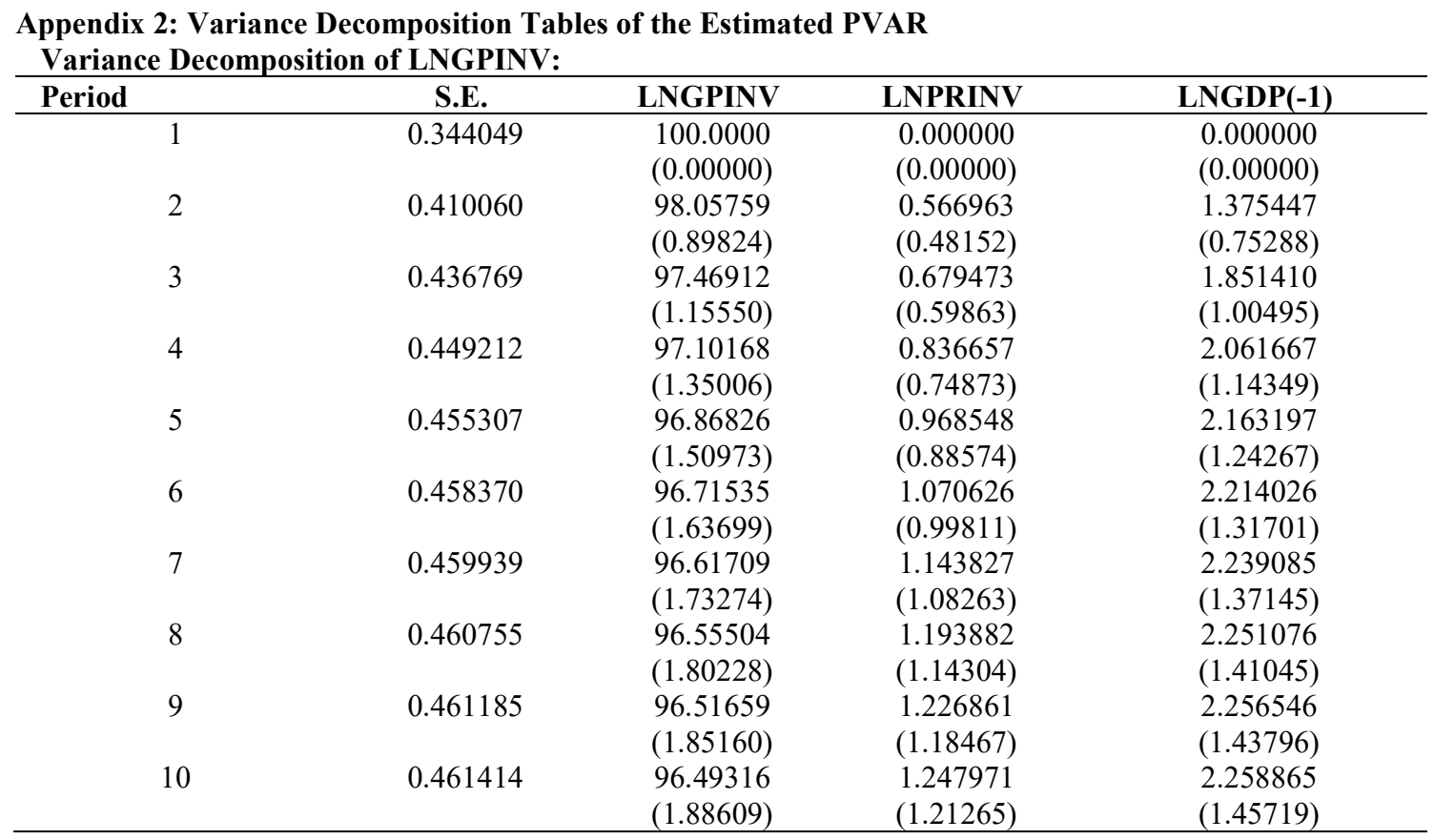




\begin{tabular}{|c|c|c|c|c|}
\hline Period & S.E. & LNGPINV & LNPRINV & LNGDP(-1) \\
\hline 1 & 0.326896 & $\begin{array}{l}0.656587 \\
(0.67415)\end{array}$ & $\begin{array}{l}99.34341 \\
(0.67415)\end{array}$ & $\begin{array}{l}0.000000 \\
(0.00000)\end{array}$ \\
\hline 2 & 0.379986 & $\begin{array}{l}0.700812 \\
(0.53414)\end{array}$ & $\begin{array}{l}98.94445 \\
(0.68698)\end{array}$ & $\begin{array}{l}0.354737 \\
(0.45310)\end{array}$ \\
\hline 3 & 0.408142 & $\begin{array}{l}0.859349 \\
(0.61792)\end{array}$ & $\begin{array}{l}98.51895 \\
(0.86044)\end{array}$ & $\begin{array}{l}0.621700 \\
(0.63095)\end{array}$ \\
\hline 4 & 0.422231 & $\begin{array}{l}1.056976 \\
(0.83605)\end{array}$ & $\begin{array}{l}98.02156 \\
(1.13419)\end{array}$ & $\begin{array}{l}0.921468 \\
(0.81702)\end{array}$ \\
\hline 5 & 0.429794 & $\begin{array}{l}1.216117 \\
(1.04702)\end{array}$ & $\begin{array}{l}97.57375 \\
(1.40219)\end{array}$ & $\begin{array}{c}1.210129 \\
(1.00600)\end{array}$ \\
\hline 6 & 0.433932 & $\begin{array}{l}1.326929 \\
(1.21411)\end{array}$ & $\begin{array}{c}97.20265 \\
(1.63642)\end{array}$ & $\begin{array}{l}1.470420 \\
(1.19192)\end{array}$ \\
\hline 7 & 0.436246 & $\begin{array}{l}1.395840 \\
(1.33318)\end{array}$ & $\begin{array}{c}96.91208 \\
(1.82742)\end{array}$ & $\begin{array}{l}1.692083 \\
(1.36135)\end{array}$ \\
\hline 8 & 0.437566 & $\begin{array}{l}1.434897 \\
(1.41286)\end{array}$ & $\begin{array}{l}96.69221 \\
(1.97767)\end{array}$ & $\begin{array}{l}1.872891 \\
(1.50682)\end{array}$ \\
\hline 9 & 0.438336 & $\begin{array}{l}1.455043 \\
(1.46367)\end{array}$ & $\begin{array}{l}96.52961 \\
(2.09317)\end{array}$ & $\begin{array}{l}2.015349 \\
(1.62605)\end{array}$ \\
\hline 10 & 0.438796 & $\begin{array}{l}1.464314 \\
(1.49478) \\
\end{array}$ & $\begin{array}{l}96.41121 \\
(2.18056) \\
\end{array}$ & $\begin{array}{l}2.124479 \\
(1.72039) \\
\end{array}$ \\
\hline \multicolumn{5}{|c|}{ Variance Decomposition of LNGDP(-1): } \\
\hline Period & S.E. & LNGPINV & LNPRINV & LNGDP(-1) \\
\hline 1 & 0.138130 & $\begin{array}{l}0.047825 \\
(0.29894)\end{array}$ & $\begin{array}{c}0.199902 \\
(0.39814)\end{array}$ & $\begin{array}{l}99.75227 \\
(0.50805)\end{array}$ \\
\hline 2 & 0.185684 & $\begin{array}{l}0.316795 \\
(0.57711)\end{array}$ & $\begin{array}{l}0.965514 \\
(0.84264)\end{array}$ & $\begin{array}{l}98.71769 \\
(1.02674)\end{array}$ \\
\hline 3 & 0.211347 & $\begin{array}{l}0.257110 \\
(0.55576)\end{array}$ & $\begin{array}{l}0.849847 \\
(0.85597)\end{array}$ & $\begin{array}{l}98.89304 \\
(1.02283)\end{array}$ \\
\hline 4 & 0.227199 & $\begin{array}{l}0.246239 \\
(0.52227)\end{array}$ & $\begin{array}{c}0.735644 \\
(0.80501)\end{array}$ & $\begin{array}{l}99.01812 \\
(0.95491)\end{array}$ \\
\hline 5 & 0.237529 & $\begin{array}{l}0.305462 \\
(0.58507)\end{array}$ & $\begin{array}{c}0.696376 \\
(0.75588)\end{array}$ & $\begin{array}{l}98.99816 \\
(0.94524)\end{array}$ \\
\hline 6 & 0.244418 & $\begin{array}{l}0.405048 \\
(0.72222)\end{array}$ & $\begin{array}{l}0.715742 \\
(0.73627)\end{array}$ & $\begin{array}{l}98.87921 \\
(1.02016)\end{array}$ \\
\hline 7 & 0.249069 & $\begin{array}{l}0.518556 \\
(0.87723)\end{array}$ & $\begin{array}{c}0.768731 \\
(0.74887)\end{array}$ & $\begin{array}{l}98.71271 \\
(1.14731)\end{array}$ \\
\hline 8 & 0.252228 & $\begin{array}{l}0.628869 \\
(1.01954)\end{array}$ & $\begin{array}{l}0.835538 \\
(0.78279)\end{array}$ & $\begin{array}{l}98.53559 \\
(1.28755)\end{array}$ \\
\hline 9 & 0.254377 & $\begin{array}{l}0.726862 \\
(1.13881)\end{array}$ & $\begin{array}{l}0.903379 \\
(0.82517)\end{array}$ & $\begin{array}{l}98.36976 \\
(1.41764)\end{array}$ \\
\hline 10 & 0.255838 & $\begin{array}{l}0.808932 \\
(1.23393)\end{array}$ & $\begin{array}{c}0.965173 \\
(0.86709)\end{array}$ & $\begin{array}{r}98.22589 \\
(1.52813)\end{array}$ \\
\hline
\end{tabular}

Source: Authors' computation from data taken from World Development Indicators (2012) 